\title{
Pengaruh Model Pembelajaran Berbasis Masalah Terhadap Kemampuan Pemecahan Masalah Hukum Newton pada Siswa Kelas X SMA Negeri 4 Palu
}

\author{
Nursita, Darsikin, dan Syamsu \\ Shitajung@yahoo.co.id \\ Pend. Fisika, FKIP, Universitas Tadulako \\ Jl. Soekarno Hatta KM. 9 Palu
}

\begin{abstract}
Penelitian ini bertujuan untuk mengetahui ada tidaknya pengaruh model pembelajaran berbasis masalah terhadap kemampuan pemecahan masalah hukum newton yang dilihat dari hasil ujian di kelas eksperimen dan kelas kontrol. Penelitian ini menggunakan eksperimen kuasi dengan desain penelitian non equivalent pretest-posttest design. Populasi penelitian adalah seluruh siswa kelas X MIA SMA Negeri 4 palu. Teknik pengambilan sampel adalah purposive sampling. Kelas X MIA II sebagai kelas eksperimen dan kelas $X$ MIA I sebagai kelas kontrol. Instrumen digunakan berupa tes esai. Analisis data menggunakan uji signifikansi ( $t$ dua pihak) pada taraf nyata 0,05 dan $\mathrm{dk}=60$ dengan uji prasyarat normalitas dan homogenitas. Hasil uji statistik diperoleh $t_{\text {hitung }}=3,38$ dan $t_{\text {tabel }}=2,00$ dengan kriteria terima $H_{0}$ jika $-2,00<t<2,00$ dan tolak $H_{0}$ dalam hal lainnya. Nilai $t_{\text {hitung }}$ berada diluar penerimaan $\mathrm{H}_{0}$ sehingga $\mathrm{H}_{1}$ diterima, sehingga dapat disimpulkan bahwa ada pengaruh model pembelajaran berbasis masalah terhadap kemampuan pemecahan masalah hukum newton pada siswa kelas X SMA Negeri 4 Palu.
\end{abstract}

Kata Kunci: Model Pembelajaran Berbasis Masalah, Kemampuan Pemecahan Masalah, Hukum Newton

\section{PENDAHULUAN}

Fisika merupakan salah satu displin ilmu yang sangat berkembang pesat, baik dari segi materi maupun kegunaannya. Sebagai bagian dari Ilmu Pengetahuan Alam, fisika banyak membahas seputar gejala dan perilaku alam yang dapat diamati oleh manusia, serta pengaplikasiannya dalam kehidupan. Melalui fisika, siswa diajak untuk mampu memahami berbagai gejala dan permasalahan, berpikir, menganalisa serta mampu memecahkan masalah.

Memecahkan masalah adalah salah satu bagian penting dalam proses pembelajaran. Pemecahan masalah (problem solving) adalah upaya siswa untuk menemukan jawaban masalah yang dihadapi berdasarkan pengetahuan, pemahaman, dan keterampilan yang telah dimiliki sebelumnya ${ }^{[1]}$.

Kemampuan pemecahan masalah adalah kemampuan individu dalam menggunakan proses berpikirnya untuk memecahkan permasalahan melalui pengumpulan faktafakta, analisis informasi, menyusun berbagai alternatif pemecahan, dan memilih pemecahan yang paling efektif ${ }^{[2]}$.

Kemampuan dalam memecahkan masalah dapat diperkuat melalui latihan yang sering dilakukan dalam kelas, dengan pemberian masalah-masalah oleh guru kepada siswa, yang dapat mengajak siswa untuk mampu menganalisa dan berpikir. untuk itu pemilihan model pembelajaran yang efektif diperlukan dalam hal ini, guna memfasilitasi siswa menjadi pembelajar mandiri dan diharapkan dapat membantu siswa memecahkan masalah.

Kenyataannya pembelajaran fisika di kelas masih menghadapi berbagai masalah. Salah satunya adalah siswa kurang berminat pada pelajaran fisika karena dianggap sulit. Pelajaran fisika yang berisi konsep, aplikasi dan perhitungan serta analisis membuat siswa merasa pelajaran ini tidak mudah dipahami. Hal inilah yang memicu siswa untuk cenderung malas dan kurang berminat baik dalam menerima pelajaran maupun mengerjakan tugas. Dan tentu saja akan mempengaruhi kemampuan siswa dalam memecahkan masalah.

Berdasarkan hasil observasi di SMA Negeri 4 Palu dan wawancara dengan guru fisika, diketahui bahwa kebanyakan siswa menganggap pelajaran fisika adalah pelajaran yang sulit, siswa cenderung malas bertanya dan menyelesaikan suatu masalah dengan meniru penyelesaian masalah yang diperagakan guru ketika membahas soal-soal.

Hal ini juga dapat dilihat melalui penelitian yang dilakukan oleh peneliti sebelumnya. 
Dimana dalam penelitiannya, diperoleh skor rata-rata kemampuan pemecahan masalah pada kelas eksperimen adalah 10,57 dan kelas kontrol adalah 9,86 dengan skor ideal kemampuan pemecahan masalah adalah 40 . Adanya perbedaan skor rata-rata dan skor ideal, mengindikasikan kurangnya kemampuan pemecahan masalah fisika siswa di SMA Negeri 4 Palu $^{[3]}$.

Berdasarkan permasalah tersebut, diperlukan adanya suatu inovasi baru dalam pembelajaran yang dapat mengajak siswa untuk mampu mengembangkan kemampuan berpikir, menganalisa, dan memecahkan masalah, serta menghilangkan anggapan siswa bahwa fisika adalah pelajaran yang sulit. Salah satunya adalah dengan memberikan permasalahan fisika yang erat kaitannya dengan kehidupan sehari-hari. Siswa akan cenderung berfikir sesuai pengalaman yang mereka alami. Hal ini juga ditunjang oleh peran guru dalam memberikan rangsangan pengetahuan, memancing siswa untuk berfikir dan menjadikan siswa pelajar aktif. Model pembelajaran yang berorientasi kearah tersebut adalah model pembelajaran berbasis masalah (Problem Based Learning).

Model pembelajaran berbasis masalah merupakan model pembelajaran yang lebih menekankan pada pemecahan masalah atau masalah sebagai titik tolak. Model pembelajaran berbasis masalah merupakan suatu model pembelajaran yang didasarkan pada permasalahan yang membutuhkan penyelidikan autentik, yakni penyelidikan yang membutuhkan penyelesaian nyata dari permasalahan yang nyata ${ }^{[4]}$.

Pembelajaran berbasis masalah dalam proses pembelajaran menuntut siswa menjadi pelaku utama. Selain itu, guru hanya sebagai fasilitator yang membantu siswa untuk dapat merekonstruksi pemikiran dan pengetahuannya, sehingga dalam pelaksanaan baik pelaksanaan belajar di dalam kelas maupun di luar kelas siswa mampu menjalankan atau menyelesaikan permasalahan yang dihadapinya ${ }^{[5]}$.

Pembelajaran berbasis masalah juga sejalan dengan kurikulum 2013. Dimana kurikulum 2013 merupakan kurikulum yang menganut pandangan dasar bahwa pengetahuan tidak dapat dipindahkan begitu saja dari guru ke peserta didik. Siswa adalah subyek yang memiliki kemampuan untuk aktif mencari, mengolah, mengkonstruksi, dan menggunakan pengetahuan. Hal ini menyebabkan pembelajaran harus berkenaan dengan pemberian kesempatan kepada siswa untuk mengkonstruksi pengetahuan dalam proses kognitifnya. Agar benar-benar memahami dan dapat menerapkan pengetahuan, siswa perlu didorong untuk bekerja memecahkan masalah, menemukan segala sesuatu untuk dirinya, dan berupaya keras mewujudkan ide-idenya ${ }^{[6]}$.

\section{METODE PENELITIAN}

Jenis penelitian yang digunakan dalam penelitian ini yaitu eksperimen semu (quasi experiment), karena tidak semua variabel yang muncul dan kondisi eksperimen dapat dikontrol secara ketat. Salah satu ciri dari penelitian ini adalah ketidakmampuan meletakkan subjek secara random pada kelompok eksperimental atau kelompok control.

Desain penelitian yang digunakan adalah nonequivalent pretest-posttest design. Penelitian dilakukan pada siswa kelas X SMA Negeri 4 Palu. Pemilihan sampel digunakan teknik purposive sampling yaitu penentuan sampel dengan pertimbangan tertentu, sehingga diperoleh kelas X MIA II sebagai kelas eksperimen dan kelas X MIA I sebagai kelas kontrol.

Data yang dikumpulkan berupa hasil tes pemecahan masalah hukum Newton, dengan instrumen yang digunakan berupa tes uraian dengan jumlah 4 butir soal.

\section{HASIL DAN PEMBAHASAN}

\section{A. Hasil}

Pada penelitian ini digunakan dua kelas yaitu kelas eksperimen dan kelas kontrol. Dengan kelas eksperimen diajar menggunakan model pembelajaran berbasis masalah, sedangkan kelas kontrol diajar menggunakan model pembelajaran konvensional berupa model pembelajaran inquiri.

Hasil tes kemampuan pemecahan masalah hukum newton berdasarkan tes awal dan tes akhir pada kelas ekperimen dan kelas kontrol dapat dilihat pada Tabel 1

\begin{tabular}{lcccc} 
TABEL I DESKRIPSI & SKOR TES & KEMAMPUAN & PEMECAHAN & MASALAH \\
HUKUM NEWTON PADA KELAS EKSPERIMEN DAN KELAS KONTROL & \multicolumn{2}{c}{ Pretest } & \multicolumn{2}{c}{ Posttest } \\
\cline { 2 - 5 } Uraian & \multicolumn{2}{c}{ Kelas } & \multicolumn{2}{c}{ Kelas } \\
\cline { 2 - 5 } & $\begin{array}{c}\text { Eksperi } \\
\text { men }\end{array}$ & Kontrol & $\begin{array}{c}\text { Eksperi } \\
\text { men }\end{array}$ & Kontrol \\
\hline Sampel (N) & 30 & 32 & 30 & 32 \\
\hline $\begin{array}{l}\text { Skor } \\
\text { Maksimum }\end{array}$ & 17 & 16 & 27 & 24 \\
\hline $\begin{array}{l}\text { Skor } \\
\text { Minimum }\end{array}$ & 6 & 6 & 16 & 13 \\
\hline
\end{tabular}




\begin{tabular}{lcccc}
\hline Rerata Skor & 11,36 & 11,00 & 21,33 & 18,28 \\
\hline Skor Ideal & 32 & 32 & 32 & 32 \\
\hline $\begin{array}{l}\text { Standar } \\
\text { Deviasi }\end{array}$ & 3,00 & 3,15 & 3,15 & 3,16 \\
\hline $\begin{array}{l}\text { \% } \\
\text { Ketercapaia } \\
\text { ndari skor } \\
\text { ideal }\end{array}$ & $36 \%$ & $34 \%$ & $67 \%$ & $57 \%$ \\
\hline
\end{tabular}

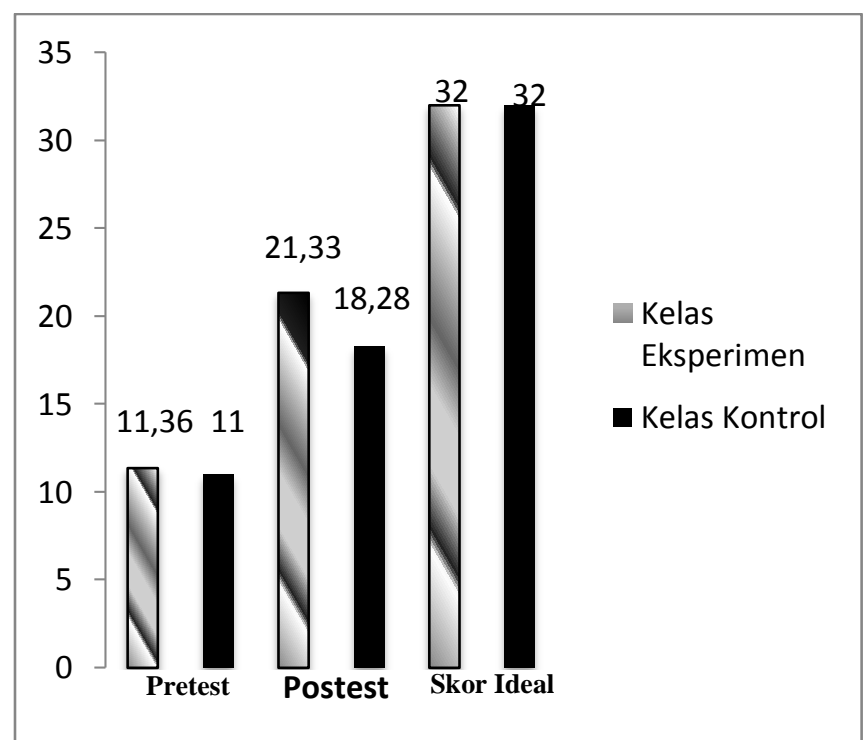

Gambar 1: Grafik Perolehan Rata-rata Skor Tes Awal dan Tes Akhir Kemampuan Pemecahan Masalah

Berdasarkan Gambar 1 perolehan skor ratarata siswa secara kuantitas terdapat perbedaan. Pada postest perbedaan yang ditunjukkan cukup signfikan dimana kelas eksperimen dengan perolehan skor tertinggi yaitu 21,33 sedangkan pada kelas kontrol dengan perolehan skor yaitu 18,28 dari skor ideal 32 .

Adapun grafik persentase skor rata-rata tes awal (pretest) dan tes akhir (postest) dari kedua kelas dapat dilihat pada Gambar 2.

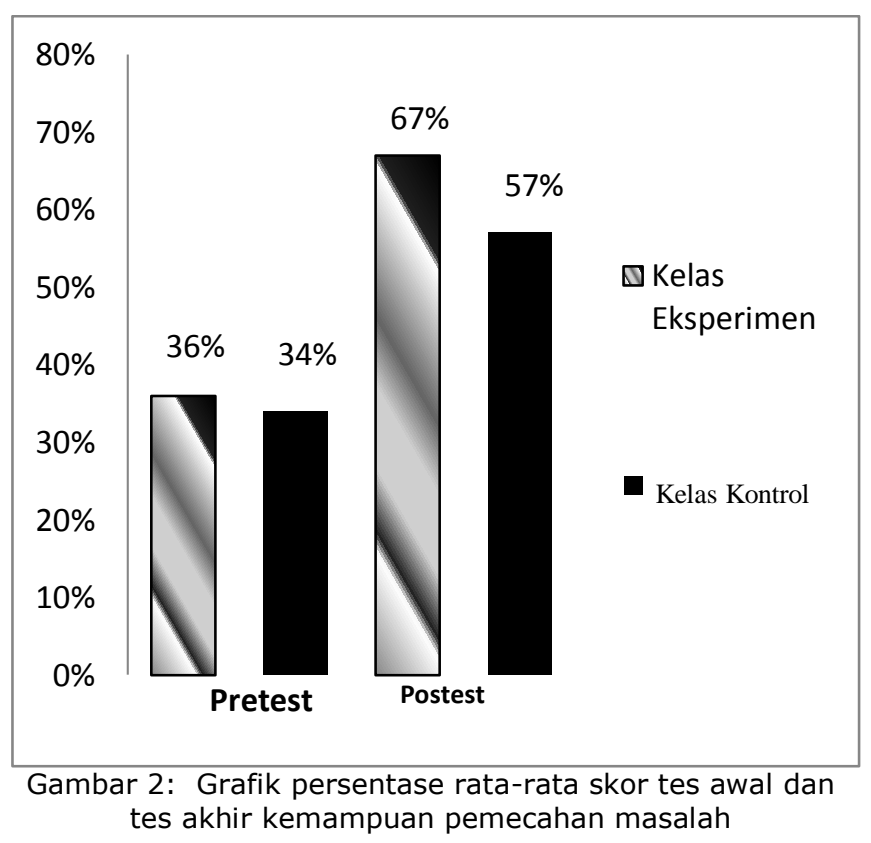

Berdasarkan Gambar 2, persentase skor ratarata tes ketercapaian kemampuan pemecahan masalah hukum newton pada tes awal dan tes akhir yang diukur dari skor ideal yakni skor rata-rata dibagi dengan skor ideal yang dikalikan dengan $100 \%$ diperoleh pada tes awal (pretest ) kelas ekperimen 36\% dan kelas kontrol 35\%, sedangkan untuk tes akhir (postest) pada kelas ekperimen $67 \%$ dan kelas kontrol 57\%. Secara kuantitas terdapat perbedaan kemampuan siswa dalam memecahkan masalah fisika antara kelas eksperimen dan kelas kontrol.

Uji normalitas dilakukan untuk mengetahui apakah data yang diperoleh berasal dari data yang berdistribusi normal atau tidak. Uji normalitas terhadap dua kelas tersebut dilakukan dengan uji chi kuadrat dengan taraf signifikansi $\alpha=0,05$. Hasil uji normalitas pada pretest dan postest dapat dilihat pada Tabel 2

TABEL 2 : NORMALITAS DISTRIBUSI TES AWAL (PRETEST) DAN TES AKHIR (POSTEST) KELAS EKPERIMEN DAN KELAS KONTROL.

\begin{tabular}{|c|c|c|c|c|c|}
\hline \multirow{2}{*}{$\begin{array}{l}\mathrm{N} \\
\mathrm{O}\end{array}$} & \multirow[b]{2}{*}{ Kelas } & \multicolumn{2}{|c|}{ Nilai $x^{2}$ Hitung } & \multirow{2}{*}{$\begin{array}{l}\text { Nilai } \\
x^{2} \text { Tabel } \\
(\alpha \\
=0,05)\end{array}$} & \multirow[b]{2}{*}{ Keputusan } \\
\hline & & $\begin{array}{c}\text { Pretes } \\
\mathrm{t}\end{array}$ & $\begin{array}{c}\text { Postes } \\
\mathrm{t}\end{array}$ & & \\
\hline 1 & $\begin{array}{c}\text { Ekperime } \\
n \\
\text { (X MIA II) }\end{array}$ & 3,14 & 4,57 & 7,81 & $\begin{array}{c}\text { Terdistribus } \\
\text { i normal }\end{array}$ \\
\hline 2 & $\begin{array}{c}\text { Kontrol } \\
\text { (X MIA I) }\end{array}$ & 3,67 & 2,64 & 7,81 & $\begin{array}{c}\text { Terdistribus } \\
\text { i normal }\end{array}$ \\
\hline
\end{tabular}

Berdasarkan hasil output pada uji normalitas seperti pada Tabel 2 untuk pretest pada kelas eksperimen diperoleh $X^{2}$ hit $=3,14$ sedangkan 
kelas kontrol diperoleh $X^{2}$ hit $=3,67$ kedua nilai signifikansi ini lebih keci dari $X^{2}$ tabel $=7,81$. Karena $X^{2}{ }_{\text {hit }}<X^{2}$ tabel maka data berdistribusi normal. Postest pada kelas eksperimen diperoleh $X^{2}$ hit $=4,57$ sedangkan kelas kontrol diperoleh $X^{2}$ hit $=2,64$ kedua nilai signifikansi ini lebih kecil dari $X_{\text {tabel }}^{2}=7,81$. Karena $X^{2}$ hit $<$ $X^{2}$ tabel maka data berdistribusi normal.

Uji homogenitas varians digunakan untuk melihat data kemampuan pemecahan masalah hukum newton bagi kelompok murid eksperimen dan kelompok kontrol dari populasi dan varians yang homogen atau tidak homogen. Jika $F_{\text {hitung }}<F_{\text {tabel }}$, maka data berasal dari populasi yang homogen.

TABEL 3 : HOMOGENITAS DUA VARIANS TES AWAL (PRETEST) DAN TES AKHIR (POSTEST) KELAS EKPERIMEN DAN KELAS KONTROL.

\begin{tabular}{|c|c|c|c|c|c|c|c|}
\hline \multirow{2}{*}{$\begin{array}{l}\mathrm{N} \\
\mathrm{O}\end{array}$} & \multirow{2}{*}{ Kelas } & \multicolumn{2}{|c|}{$\begin{array}{c}\text { Nilai } \\
\text { Varians } \\
\end{array}$} & \multicolumn{2}{|c|}{$\begin{array}{l}\text { Varians } \\
\text { Hitung }\end{array}$} & \multirow{2}{*}{$\begin{array}{c}\text { Nilai } \\
\text { F } \\
\text { Tabel } \\
(\alpha= \\
0,05)\end{array}$} & \multirow{2}{*}{$\begin{array}{c}\text { Keputu } \\
\text { san }\end{array}$} \\
\hline & & $\begin{array}{l}\text { Pret } \\
\text { est }\end{array}$ & $\begin{array}{l}\text { Post } \\
\text { est }\end{array}$ & $\begin{array}{l}\text { Pret } \\
\text { est }\end{array}$ & $\begin{array}{c}\text { Post } \\
\text { est }\end{array}$ & & \\
\hline 1 & $\begin{array}{c}\text { Eksperi } \\
\text { men } \\
\text { (X MIA } \\
\text { II) }\end{array}$ & $\begin{array}{c}9,0 \\
2\end{array}$ & $\begin{array}{c}9,9 \\
7\end{array}$ & $\begin{array}{c}1,1 \\
0\end{array}$ & $\begin{array}{c}1,0 \\
3\end{array}$ & 1,88 & \multirow{2}{*}{$\begin{array}{l}\text { Kedua } \\
\text { data } \\
\text { homog } \\
\text { en } \\
\text { (pretes } \\
\text { t dan } \\
\text { postest } \\
\text { ) }\end{array}$} \\
\hline 2 & $\begin{array}{c}\text { Kontrol } \\
\text { (X MIA } \\
\text { I) }\end{array}$ & $\begin{array}{l}9,9 \\
6\end{array}$ & $\begin{array}{l}10 \\
04\end{array}$ & $\begin{array}{c}1,1 \\
0\end{array}$ & $\begin{array}{c}1,0 \\
3\end{array}$ & 1,88 & \\
\hline
\end{tabular}

Berdasarkan hasil output pada uji homogenitas seperti pada Tabel 3 dengan taraf signifikansi $(\alpha=0,05)$ untuk pretest diperoleh $F_{\text {hitung }}$ sebesar 1,10 dan $F_{\text {tabel }}$ sebesar 1,88 sedangkan untuk postest diperoleh $F_{\text {hitung }}$ sebesar 1,03 dan $F_{\text {tabel }}$ sebesar 1,88. Dari data tersebut terlihat bahwa $F_{\text {hitung }}$ baik pada pretest maupun pada postest lebih kecil dari $F_{\text {tabel, }}$ sehingga berdasarkan kriteria pengambilan keputusan dapat disimpulkan bahwa tidak terdapat perbedaan varians antara kelas eksperimen dan kelas kontrol (varians kelas eksperimen dan kelas kontrol sama) dengan kata lain datanya bersifat homogen.

Berdasarkan hasil uji normalitas dan uji homogenitas yang telah dilakukan, diperoleh data yang berdistribusi normal dan homogen sehingga dapat dilakukan uji kesamaan ratarata dengan menggunakan uji signifikansi (dua pihak). Uji ini digunakan untuk memastikan apakah hipotesis yang diajukan dapat diterima atau ditolak.

Hasil perolehan pengujian statistik uji signifikansi data hasil kemampuan siswa dalam pemecahan masalah hukum newton antara kelas eksperimen dan kelas kontrol ditunjukkan pada Tabel 4
TABEL 4: UJI DUA PIHAK TES AWAL (PRETEST) DAN TES AKHIR (POSTEST) KELAS EKPERIMEN DAN KELAS KONTROL

\begin{tabular}{|c|c|c|c|c|c|c|c|c|}
\hline \multirow{3}{*}{$\begin{array}{l}\mathrm{N} \\
\mathrm{O}\end{array}$} & \multirow{3}{*}{ Kelas } & \multirow{2}{*}{\multicolumn{2}{|c|}{$\begin{array}{c}\text { Nilai } \\
\text { Rata- } \\
\text { Rata } \bar{X} \\
\end{array}$}} & \multirow{2}{*}{\multicolumn{2}{|c|}{$\mathrm{t}_{\text {Hitung }}$}} & \multirow{3}{*}{$\begin{array}{c}\mathrm{t}_{\mathrm{tab}} \\
\text { el } \\
( \\
\alpha= \\
0,05 \\
)\end{array}$} & \multirow{2}{*}{\multicolumn{2}{|c|}{ Keputusan }} \\
\hline & & & & & & & & \\
\hline & & $\begin{array}{c}\text { Pre } \\
\text { tes } \\
t \\
\end{array}$ & $\begin{array}{l}\text { Pos } \\
\text { test }\end{array}$ & $\begin{array}{l}\text { Pre } \\
\text { test }\end{array}$ & $\begin{array}{c}\text { Pos } \\
\text { tes } \\
t \\
\end{array}$ & & $\begin{array}{c}\text { Prete } \\
\text { st }\end{array}$ & $\begin{array}{c}\text { Post } \\
\text { est }\end{array}$ \\
\hline
\end{tabular}

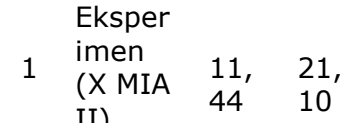

II)

2 I $\begin{array}{lll}\text { Kontro } & & \\ \text { (X MIA } & 11, & 18, \\ \text { I) } & 37\end{array}$

$0,3 \quad 3,3 \quad 2,0 \quad \begin{array}{ccc}\mathrm{H}_{\circ} & \mathrm{H}_{1}\end{array}$ ima ima

I)

Berdasarkan Tabel 4 terlihat bahwa, pada tes awal (pretest) nilai $t_{\text {hitung }}$ sebesar 0,31 dan nilai $t_{\text {tabel }}$ pada taraf signifikansi $(a=0,05)$ sebesar 2,00 hasil pengujian ini menunjukkan $t_{\text {hitung }}$ berada pada daerah penerimaan $\mathrm{H}_{0}$, yakni $t_{\text {hitung }}$ $<t_{\text {tabel }}$ dengan demikian $\mathrm{H}_{\mathrm{o}}$ diterima dan $\mathrm{H}_{1}$ ditolak artinya tidak terdapat perbedaan kemampuan pemecahan masalah hukum newton antara kelas ekpserimen dan kelas kontrol.

Untuk pengujian hipotesis berdasarkan tes akhir (postest) diperoleh nilai sebesar 3,38 dan nilai $t_{\text {tabel }}$ pada taraf signifikansi $(a=0,05)$ sebesar 2,00 hasil pengujian ini menunjukkan $t_{\text {hitung }}$ berada pada daerah penerimaan $\mathrm{H}_{1}$, yakni $t_{\text {hitung }} \geq t_{\text {tabel }}$ dengan demikian $\mathrm{H}_{1}$ diterima dan $\mathrm{H}_{0}$ ditolak artinya terdapat perbedaan yang signifikan antara kemampuan pemecahan masalah hukum newton kelas eksperimen dan kelas kontrol.

Berdasarkan uji hipotesis diatas dapat diketahui, bahwa kedua kelas memiliki perbedaan, dengan kelas eksperimen memiliki nilai rata-rata postest yang lebih tinggi dibanding kelas kontrol. Sehingga mengindikasikan bahwa model pembelajaran berbasis masalah memiliki pengaruh terhadap kemampuan pemecahan masalah hukum newton.

\section{B. Pembahasan}

Penelitian ini bertujuan untuk mengetahui ada tidaknya pengaruh model pembelajaran Berbasis Masalah (Problem Based Learning) terhadap kemampuan pemecahan masalah fisika pada materi hukum newton. Pada penelitian ini digunakan dua sampel yaitu kelas eksperimen dan kelas kontrol. Pada awal penelitian kedua kelas ini diberikan tes awal atau pretest. Kemudian data pretest dianalisis untuk mengetahui bahwa kedua data tersebut berasal dari varians yang sama (homogen) atau 
memiliki kemampuan yang kurang lebih sama. Selanjutnya kelas eksperimen menggunakan model pembelajaran berbasis masalah, sedangkan kelas kontrol menggunakan model pembelajaran inquiri.

Tahapan pembelajaran berbasis masalah dimulai dengan: (1) orientasi siswa terhadap masalah, (2) mengorganisasi siswa untuk belajar, (3) membimbing penyelidikan individual dan kelompok, (4) mengembangkan dan menyajikan hasil karya, (5) menganalisis dan mengevaluasi proses pemecahan masalah.

Pada tahap awal peneliti menyampaikan tujuan pembelajaran dan memberi pertanyaan awal yang merangsang pengetahuan awal siswa. Salah satu contohnya, peneliti menanyakan materi hukum Newton I: "Pernakah kalian mengendarai sebuah kendaraan, kemudian tiba-tiba kendaraan tersebut berhenti. Apa yang terjadi pada tubuh kalian?". Secara antusias siswa menjawab pertanyaan yang diberikan sesuai dengan pengalaman mereka. Sebagian siswa menjawab bahwa tubuh mereka terdorong kedepan ketika kendaraan yang mereka tumpangi berhenti mendadak. Untuk lebih jelasnya, peneliti meminta dua orang siswa mendemosntrasikan langsung di depan kelas. Dua orang siswa tersebut diminta berlari kemudian dengan tiba-tiba berhenti. Melalui demonstrasi tersebut siswa lainnya dapat melihat bagaimana tubuh teman mereka saat berhenti. Kemudian peneliti bertanya kepada siswa, "kenapa bisa demikian?" Sebagian siswa ada yang bingung dan beberapa diantaranya menyatakan bahwa ini ada hubungannya dengan hukum newton. Ketika ditanyai lebih lanjut mengenai hukum newton tersebut, siswa juga masih bingung tentang hal tersebut. Peneliti belum memberikan jawaban melainkan meminta siswa untuk menemukan jawabannya melalui praktikum yang akan mereka lakukan menyangkut hukum I Newton.

Siswa kemudian dibagi menjadi beberapa kelompok, tiap kelompok terdiri 5 atau 6 orang siswa. Kemudian peneliti memberikan lembar kerja siswa pada masing-masing kelompok. Pada tahap ini siswa didorong untuk melakukan kerjasama dengan melakukan praktikum sesuai langkah kerja pada LKS. Namun sebelum itu, siswa diarahkan untuk membaca masalah yang tersedia di LKS. Masalah yang diberikan merupakan masalah autentik yang sering mereka alami. Berdasarkan masalah tersebut, siswa diarahkan untuk melakukan praktikum sesuai petunjuk LKS. Seperti pada kegiatan praktikum hukum I Newton, siswa menggunakan media sederhana berupa kaleng dan selembar kertas. kaleng yang digunakan ada dua buah, yaitu kaleng kosong dan kaleng yang masih berisi minuman. Siswa melakukan perlakuan pertama dengan menggunakan kaleng kosong. Sesuai petunjuk praktikum, pertama-tama kaleng ditarik secara perlahan kemudian ditarik dengan cepat. Lalu siswa mengamati apa yang terjadi. Siswa melihat bahwa kaleng kosong tersebut terjatuh ketika ditarik dengan cepat, berbeda jika ditarik dengan pelan.

Kemudian perlakukan kedua dengan menggunakan kaleng yang berisi minuman, siswa menarik kaleng berisi tersebut menggunakan kertas dengan perlahan, kemudian ditarik dengan cepat. Siswa melihat adanya perbedaan. Pada kaleng kedua ketika ditarik dengan cepat, kaleng tersebut bergerak tapi tak jatuh seperti kaleng pertama. Siswa kemudian menuliskan hasil pengamatan mereka pada LKS.

Di dalam lembar LKS, siswa melakukan analisis masalah. Pada awalnya siswa menulis masalah yang dialami dalam wacana tersebut. Lalu siswa menuliskan fakta-fakta yang ada, barang-barang apa saja yang terlihat di wacana dengan benda yang mereka miliki. kemudian siswa melakukan langkah-langkah pemecahan masalah. Pada langkah-langkah pemecahan masalah, siswa menuliskan kegiatan yang mereka lakukan dalam memecahkan masalah melalui kegiatan praktikum yang mereka lakukan. Berdasarkan hal tersebut, siswa menghubungkan masalah yang dialami dalam wacana dengan praktikum yang mereka lakukan. Siswa juga diarahkan untuk membaca buku referensi, agar proses pemecahan masalah dapat berlangsung dengan baik.

Berdasarkan praktikum yang dilakukan oleh siswa, mereka mengetahui bahwa masalah yang dialami Andi dalam wacana merupakan salah satu contoh hukum I Newton tentang kelembaman. Kaleng yang terjatuh ketika kertas ditarik menunjukkan bahwa kaleng tersebut cenderung mempertahankan posisinya sesuai dengan hukum I Newton. Siswa melihat kelembaman yang terjadi pada dua benda dengan massa yang berbeda, melalui dua kaleng berbeda massa ini siswa menjadi tahu bahwa kelembaman benda bergantung pada massanya. Semakin besar massa benda tersebut maka kelembamannya akan semakin b besar, hal ini dapat dilihat pada kaleng yang masih berisi minuman cenderung tetap mempertahankan posisinya dengan bergerak tanpa terjatuh seperti kaleng yang kosong. 
Selanjutnya peneliti membimbing siswa untuk menyajikan hasil kerja mereka. Siswa dapat saling bertukar pendapat antara kelompok dan menyampaikan pendapat mereka secara terbuka pada teman sekelas. Kemudian peneliti membantu siswa mengkaji ulang hasil pemecahan masalah. Mengevaluasi konsepkonsep yang salah dengan menjelaskan materi secara keseluruhan.

Diakhir pembelajaran siswa kemudian melaksanakan posttest. Analisis data hasil posttest dilakukan dengan tujuan untuk mengetahui pengaruh model pembelajaran berbasis masalah terhadap kemampuan pemecahan masalah pada materi hukum newton. Selanjutnya dengan menggunakan rata-rata skor posttest dimana pada masingmasing kelas telah diberi perlakuan sehingga diperoleh nilai $t_{\text {hitung }}=3,38$ dan nilai $t_{\text {tabel }}=2,00$. Dengan demikian diperoleh $\mathrm{H}_{1}$ diterima sedangkan $\mathrm{H}_{0}$ ditolak. Artinya ada perbedaan yang signifikan antara kemampuan pemecahan masalah hukum newton siswa yang mendapat pembelajaran dengan menggunakan model pembelajaran berbasis masalah dan siswa yang mendapatkan pembelajaran dengan model pembelajaran inquiri.

Diperolehnya hasil tersebut karena dalam pembelajaran menggunakan model pembelajaran berbasis masalah, siswa dilatih dengan memberikan masalah yang berkaitan seputar kehidupan sehari-hari dan belajar sesuai pengalaman mereka. Siswa juga berperan aktif dalam proses pembelajaran dan secara kreatif berusaha menemukan solusi dari permasalahan yang diajukan, saling berinteraksi dengan teman maupun guru, saling bertukar pikiran, sehingga wawasan dan daya pikir mereka berkembang dan menyadari banyak hal atau kejadian yang dapat mereka jumpai dalam kehidupan sehari-hari yang berkaitan dengan konsep fisika yang mereka pelajari.

Melalui pembelajaran berbasis masalah siswa dapat terlatih belajar mandiri dan memecahkan masalah. Siswa cenderung belajar sesuai pengalaman mereka sehari-hari. Hasil ini sejalan dengan kelebihan model pembelajaran berbasis masalah yang ada pada literatur dimana siswa dapat mengingat, menerapkan dan melanjutkan proses belajar secara mandiri dan siswa dapat mengimplementasikan pengetahuan untuk memecahkan masalah.
Pernyataan tersebut juga didukung oleh hasil penelitian sebelumnya diamana kemampuan memecahkan masalah fisika pada siswa yang diajar dengan menggunakan model pembelajaran berbasis masalah lebih tinggi dibanding menggunakan pembelajaran konvensional. Menurutnya perbedaan ini disebabkan karena, pemberian materi menggunakan model pembelajaran berbasis masalah lebih menekankan pada permasalahan-permasalahan yang berkaitan erat dalam kehidupan, sehingga siswa tertarik dalam mengikuti pembelajaran ${ }^{[7]}$.

\section{KESIMPULAN}

Berdasarkan analisis data, maka dapat disimpulkan bahwa terdapat pengaruh model pembelajaran berbasis masalah terhadap kemampuan pemecahan masalah hukum Newton pada siswa kelas X SMA Negeri 4 Palu .

\section{DAFTAR PUSTAKA}

[1] Santyasa, I W. 2004. Model problem solving dan reasoning sebagai alternatif pembelajaran inovatif. Makalah. Disajikan dalam Konvensi Nasional Pendidikan Indonesia (Konaspi) V, tanggal 5-9 Oktober 2004, di Surabaya. Inpress.

[2] Dwi. I M., Arif. M, \& Sentot. K. 2013. Pengaruh Strategi Problem Based Lerning Berbasis ICT Terhadap Pemahaman Konsep dan Kemampuan Pemecahan Masalah Fisika. Jurnal Pendidikan Fisika Indonesia [online] 9 (2013) 8-17. Tersedia pada http:// journal.unnes.ac.id/nju/index.php/jpfi. [ [2 Februari 2014].

[3] Hariawan. 2014. Pengaruh Model Pembelajaran Creative Problem Solving Terhadap Kemampuan Memecahkan Masalah Fisika Pada Siswa Kelas XI SMA Negeri 4 Palu. Skripsi FKIP Universitas Tadulako Palu. Unpublished.

[4] Trianto. 2009. Mendesain Model Pembelajaran Inovatif-Progresif. Jakarta : Kencana Pernada Group.

[5] Resianto, Sidiq. 2010. Penerapan Pendekatan Konstruktivistik Dengan Problem Based Learning Dalam Peningkatan Kemampuan Memecahkan Masalah Siswa dalam Pembelajaran Aqidah Akhlak di SMK NU 1 Kedungpring Lamongan. Skripsi Pada Universitas Islam Negeri Maulana Malik Ibrahim Malang. Unpublished.

[6] Kemdikbud. 2014. IImu Pengetahuan Alam. Pusat Kurikulun dan Perbukuan, Balitbang, Kemdikbud: Jakarta.

[7] Nurhayati. (2009). Peranan model pembelajaran berbasis masalah terhadap kemampuan memecahkan masalah fisika pada siswa SMA Negeri 1 Anggeraja Kabupaten Enrekang. JSPF [online]. 9. 43-50. Tersedia pada http://digilib.unm.ac.id. [ 2 Februari 2014]. 